Volume 5 Issue 2, June 2018

\title{
The Certainty And Legal Protection To The Buyer's Auction Of The Mortgage Right Object On Online Auctions At The Service Of Wealth State Office And Auction (KPKNL)
}

\begin{abstract}
Arif Budi Pamungkas ${ }^{1}$, Zaldy Kurniawan ${ }^{2}$ and Djauhari ${ }^{3}$
Abstract. An auction is an activity of selling of goods in public by means of a verbal-bid to get the higher price or to get lower prices and the price quote can be done in a closed and written. This is done by the way of collecting the prospective buyers of the auction led by officials of the auction. In this case, the intended auction was the sale of goods that are held publicly. The auction, according to the regulations of security right, is when the debtor made a breach, the holder of the security rights have the right to sell the security rights' objects over its own power through a public auction as well as taking payment of account receivable from the sale proceeds. An auction is an alternative to the sale of an undertaken asset by way of inviting prospective buyers at a particular time and place in which the last highest bidder in writing or orally is determined as the winner. The author used socio-legal research as his research method. To meet the forth standards set by the law, the auction should be widely announced to the public, either through printed file, electronic or visual. A legal certainty as a basis which concerned with propriety and justice is very closely related to the principle of auction sales in another. As the formulation of the problem of the form of identification of the problem, namely how the legal protection of the auction buyers encountered the obstacles as well as the solution.

Keywords: Auction; Legal Protection; Mortgage Right.
\end{abstract}

\section{Introduction}

An auction is an activity of selling of goods in public by means of a verbal-bid to get the higher price or to get lower prices and the price quote can be done in a closed and written. This is done by the way of collecting the prospective buyers of the auction led by officials of the auction ${ }^{4}$. The auction object security right intimately connected with the tort of the creditor against the debtor. A tort is a credit agreement that is followed by the security rights, the debtor is no longer affording or lack of faith of the good to pay its obligations to the lender, so that the goods will be loaded in the guarantees of the security right to sell to another party to pay off the obligations of debtor against creditors (usually with the auction process guarantees).

The auction on Mortgage Right object is one way of obtaining land rights. The transition of land rights through auctions conducted in order to repay the debt is guaranteed by a security right.

The formulation of article 14 paragraph (2) UUHT clearly stating that the certificate of security rights has the power of executable as well as a ruling court that has magnitude. There are several ways of doing the bidding of the filing in an auction through Service Office a wealth of State and Auction (KPKNL), which has been set up

\footnotetext{
1 Master of Notary's Student, Faculty of Law, Universitas Islam Sultan Agung email arifbudipam@gmail.com

2 Students of Master of Law, Faculty of Law, Universitas Islam Sultan Agung email zaldykurniawan2008@gmail.com

${ }^{3}$ Lecturer of Faculty of Law UNISSULA

${ }^{4}$ Sutarjo 1995 "Pelelangan Dalam Eksekusi Oleh Pengadilan Negeri dan PUPN Serta AspekAspek Hukum yang Timbul Dalam Praktek" Paper of Lelang Medan p. 22.
} 
in article 54 of the financial regulation of the Minister (FMD) number 93/FMD. 06/2010 as amended in FMD Number 106/ FMD. 06/2013 Auction Guidelines, about the bidding auction direct and/or indirect bidding auction are done by means of:

- Oral, increasing or declining;

- Written; or

- Written followed by oral, in terms of the highest bidding has not reached the Limit Value.

There are two types of bidding auction i.e. direct and indirect. For direct bidding auction, a bidder or his power at the time of execution of the auction must present at the place of execution of the auction. In the other word quote directly is the kind of offer that conventional or common, prior to the bidding rules indirectly/online. Thus, the principle of certainty of law between the parties, seller, buyer, the previous landlord, as well as other parties with an interest in it, it is very directly visible until the determination of the winner of the auction.

Legal certainty as a basis which concerned with the propriety and justice, is very closely related to another principle in i.e. auction sales: ${ }^{5}$ open/transparent, competitive, reasonable price/optimal.

The buyer was appointed upon the bidder who did an offering with the highest price and the price has reached or exceeded the limit price, so it would be found an optimal price of goods with reasonable prices in general.

Furthermore, in an indirect bidding auction, the legitimate auction participants or its attorney at the time of execution of the auction are not required to be present at the place of execution of the auction and its bid is done with the use of information and technology communication. The legal size or illegal size of the auction participants that followed the auction process has passed the qualification of the terms of the online auction process suitable with FMD No. 106/FMD. 06/2013 about Auction Guidelines. In article 54 paragraph (3) explained that the bidding auction in writing without the presence of the bidder can be done by electronic mail (email); mail; or via the internet. It is strengthened with the inception of the Act No. 11 of 2008 on the information and electronic transactions (ITE). Article 1 number 4 of the ACT ITE explained that the electronic document is any electronic information that are made, forwarded, transmitted, received, or stored in the form of analog, digital, coaxial, elektomagnetik or like, which can be seen, displayed, and/or heard through a computer or electronic systems, including but not limited to text, sound, pictures, maps, drafts, photos or the like, letters, marks, numbers, access codes, symbols or perforations which have meaning or it can be understood by people who are able to understand it. Based on the definition of terms and the mechanism of bidding auction has gotten an expansion, especially from a media that is used to hold the auction. The auction is no longer the only sales of goods that are directly opened to the public, but also indirectly, through the electronic media that is the internet, and the electronic document is valid. It is according to the law against online auction process according to article 54 paragraph (3) of the FMD No. 106/FMD. 06/2013, even that has been printed.

The existence of an online auction system, it doesn't mean being a guarantee of legal certainty or the principle of associated in it, such as transparency, competitive or optimal price will be fulfilled. In other words, online auctions can be a breakthrough of the auction system conventionally, or vice versa, can be an opportunity for those who

\footnotetext{
${ }^{5}$ Departemen Keuangan Republik Indonesia 1995 Lelang Barang-Barang Milik Badan Usaha Milik Negara/Daerah. Bandung: Official Region IV National Auction Department p. 1.
} 
are not liable to take advantage inside, the problem may appear on how a Certainty and legal protection of the buyer auction, encountered obstacles and solutions.

\section{Research Methods}

Approach to the problem that is used in this research is the legal approach in sociolegal research. Research that is legal just puts socio-legal as social symptoms. The law is viewed from the outside just always associates with social problems, this research is the specification including analytical, descriptive, i.e. an approach that describes the prevailing regulations associated with the theories of law implementation and practice of positive law that concerns the issues raised in the study, ${ }^{6}$ which is about legal protection of Buyers of the auction over the Privileges object of security rights on Online auction at Service Wealth State Office and State Auction Office (KPKNL).

\section{Discussion}

The ease and excess of the Execution of Security Rights article 6 on legislation of Security Right id not persistently can be utilized by the bank as an alternative to the completion of bad debt that is secured by security rights. There are many factors that lead to the process of the execution of security rights which cannot run properly. The factor of these problems included several things, they are the mismatch of the legal substance of the legislation the security right, which governing the Execution of Security Rights itself, the actions and the paradigm from law enforcement agencies, as well as the culture of law in the society as well as the paradigm of the debtor as the parties that executed the security right. Therefore, this study used the theory of legal certainty as the certainty of party creditors to be able to execute directly the security rights which is made as the collateral credit. In 1748 Moentesquieu wrote the book De esprit des Lois (The Spirit of Laws) as a reaction against the arbitrariness of the monarchy, because the Head of the house of the Kingdom's is very determining the legal system of the judiciary at that time in the service of the monarchy significantly. ${ }^{7}$

In 1764 an Italian legal thinker named Gesare Beccaria wrote a book with the title of De delliti $e$ delle pene, who implemented the idea of Moentesquieu in the field of criminal law. For him, a person can be punished if that action had been decided by the previous legislation, therefore, the Executive is being able to crack down on and punish if there is someone who is violating what has been decided by the legislature. This idea is known as the principle of nullum crimen sine legi, which has a goal. The goal is giving legal protection to every citizen who against the arbitrariness of the country. ${ }^{8}$

According to Gustav Radbruch as quoted by Theo Huijbers: ${ }^{9}$

According to Radbruch, the law can be distinguished into three aspects which all three are needed to arrive at an adequate understanding of the law. The first aspect is the fairness in the narrow sense. This justice means an equality for all people in front of the Court. The second aspect is the purpose of Justice or finality. This aspect is determining the content of the law, because the content of the law is needed to

\footnotetext{
${ }^{6}$ Ronny Hanitdjo Soemitro 1900 Metodologi Penelitian Hukum dan Jurimetri Ghalamania Indonesia Jakarta p. 97.

${ }^{7}$ E. Utrecht dan Moh. Saleh J. Jindang 1989 Pengantar Dalam Hukum Indonesia Iktiar Baru dan Sinar Harapan Jakarta p. 388.

${ }^{8}$ E. Fernando M. Manullang 2007 Menggapai Hukum Berkeadilan Tinjauan Hukum Kodrat dan Antinomi Nilai PT. Kompas Media Nusantara Jakarta pp 93.

${ }^{9}$ Theo Huijbers 2007 Filsafat Hukum Dalam Lintas Sejarah Fourteenth Editiona Kanisius Yogyakarta p.163.
} 
achieve the goals. The third aspect is the certainty of law or legal. That aspect ensures that the law can serve as the rules that must be adhered to.

According to Peter Mahmud Marzuki: ${ }^{10}$

Legal certainty contains two meanings, namely; first, the existence of rules that are common to make individuals know the deeds may or may not do. Second, in the form of legal security for the individual from the arbitrariness of Government because of the existence of a rule that is common that individuals can find out anything that may be imposed or carried out by the State against individuals. Legal certainty is not just in the form of articles in regulations, but also there is a consistency in the verdict of the judges between one verdict to judge the other verdict for similar cases that had been disconnected.

Legal certainty according to Sudikno Mertokusumo, is one of the conditions that must be met in the implementation of the rule of law. Sudikno Mertokusumo defines legal certainty is a protection against the arbitrary actions of justiciable, which means that someone will be able to earn something to expect in certain circumstances. ${ }^{11}$

Bachsan Mustafa reveals, that legal certainty has three meanings: ${ }^{12}$

First, it is about the rules which is governing the law of a certain abstract issue of Government. Second, about the legal position regarding the subject and the object of the law in the exercise of State administration law regulations. Third, to prevent the possibility of any such arbitrary deeds from any party, as well as the actions of the authorities.

Legal certainty, according to Van Kan stated that, the law is in charge of guaranteeing legal certainty in human intercourse ${ }^{13}$. More, Van Kan stated: ${ }^{14}$

Legal certainty is the legal system of a country that is able to guarantee the rights and obligations of every citizen. The legal certainty is distinguished into two kinds, namely: 1) the certainty because of law means the law guarantee the certainty between one party against the other party. It means to say the existence of the consistency of application of the law to all people indiscriminately, and, 2) certainty in or from law, it means that legal certainty is achieved if the law as many as the legislation, there is no provision to the contrary (legislation based on logical and definitely systems), made based on the reality of the law (rechtswerkelijkheid) and in it there is no term that can be interpreted broadly and vary (closed).

In the credit banking agreement always occurs the possibility of the debtor to make a tort. In case of tort, the injured party would certainly not want the creditors and the debtor to debt repayment by executing the guarantee. But, it is often that the debtor objecting and not willing to voluntarily vacate the object of security right, even defended by seeking an extension of credit or through execution of Security Rights by resistance lawsuit to the District Court, that is the objective to put off the execution of security rights. This attitude disrupted order and legal certainty. Therefore, in this study used the theory of legal certainty.

The theory of legal certainty which is used in this study refers to the opinions of Peter Mahmud Marzuki that is stating the legal certainty make individuals know what deed could or could not be done, and the legal security for individuals from the arbitrariness

\footnotetext{
${ }^{10}$ Peter Mahmud Marzuki 2008 Pengantar IImu Hukum Kencana Prenada Media Group Jakarta p.158.

${ }^{11}$ Sudikno Mertokusumo 2007 Mengenal Hukum Sebuah Pengantar Liberty Yogyakarta p. 145.

12 Bachsan Mustafa 2001 Sistem Hukum Administrasi Negara Indonesia Citra Aditya Bhakti Bandung p. 53.

${ }^{13}$ E. Utrecht dan Moh. Saleh J. Jindang Op.cit. p. 390.

${ }^{14}$ E. Fernando M. Manullang Op.cit. p. 94.
} 
Volume 5 Issue 2, June 2018

of the Government, including the presence of the judge's verdict in the consistency between the ruling of the judge's verdict with one another for a similar case which has been terminated.

The winner of the auction as a legitimate buyer has a weak position object related to the auctions. In article 67 of regulation of Finance Ministers number 93/FMD.06/2010 provides the preventive protection to the owner of the object. Based on this provision, the winner of the auction must implement its obligations, so that he/she can control the object. This chapter has reflected the existence of legal certainty for owners of the objects and the seller (the lender) upon the payment of the sale in an auction by the winner of the auction. In addition to the preventive legal protection, the winner of the auction also gets a security right execution protection repressively. According to Hadjon, repressive protection is an exertion to gain legal protection through the judicial bodies. The protection toward the repressive winner of the auction of execution the security rights is contained in Article 200 HIR. Then, based on the provisions of article 200 subsection (11) of HIR. If a winner of the auction of the execution of security rights cannot master the objects that have been purchased through an auction process, so that is is valid for the sake of the law. Then the winner of the auction may request any assistance to the District Court for the discharge of such objects. In this provision gives the principle of legal certainty for the auction winner to be able to master the auction object. In article 42 Vendu Reglement, that the winner of the auction has the right to obtain the treatise quote auction as a deed of sale and purchase of the auction object. In General Vendu Reglement just set, about organizing of the auction, the auctioneer or currently known as the auction officials, is the parts of the contents of the treatise of the auction. But apparently Reglement Vendu did not arrange the reflecting provisions of the principle of legal certainty for the auction winner. In addition to Vendu Reglement as customary auction, the auction on the implementation of technical regulations of the execution of security rights currently in force, is the regulation of the Minister of finance Number 106/FMD. 06/2013 about the changes of the regulation of the Minister of finance Number 93/FMD. 06/2010 about the Guidelines and regulations of the Secretary of the Treasury Auction Number 93/FMD. 06/2010 about the auction Guidelines.

\section{Conclusion}

- Article 67 of the regulation of Finance Ministers number 93/FMD.06/2010 provides the preventive protection to the owner of the object. Based on this provision, then the auction winner must implement its obligations, so that the object can be controlled. This chapter has reflected the existence of legal certainty for the owners of the objects and the seller (the lender) upon payment of the sale in an auction by the auction winner.

- When the buyer could not master the auction object, then the auction winner may request any assistance to the District Court for the discharge of such objects. In this provision, it gives the principle of legal certainty for the auction winner to be able to master the auction object. In article 42 Vendu Reglement, that the winner of the auction has the right to obtain the treatise quote auction as a deed of sale and purchase the auction object.

- The winner of the auction is entitled to get treatise auction to be a strong evidence when there is a lawsuit.

\section{References}


[1] Sutarjo 1995 "Pelelangan Dalam Eksekusi Oleh Pengadilan Negeri dan PUPN Serta Aspek-Aspek Hukum yang Timbul Dalam Praktek' Paper of Lelang Medan.

[2] Departemen Keuangan Republik Indonesia 1995 Lelang Barang-Barang Milik Badan Usaha Milik Negara/Daerah. Bandung: Official Region IV National Auction Department.

[3] Ronny Hanitdjo Soemitro 1900 Metodologi Penelitian Hukum dan Jurimetri Ghalamania Indonesia Jakarta.

[4] E. Utrecht dan Moh. Saleh J. Jindang 1989 Pengantar Dalam Hukum Indonesia Iktiar Baru dan Sinar Harapan Jakarta.

[5] E. Fernando M. Manullang 2007 Menggapai Hukum Berkeadilan Tinjauan Hukum Kodrat dan Antinomi Nilai PT. Kompas Media Nusantara Jakarta.

[6] Theo Huijbers 2007 Filsafat Hukum Dalam Lintas Sejarah Fourteenth Editiona Kanisius Yogyakarta.

[7] Peter Mahmud Marzuki 2008 Pengantar IImu Hukum Kencana Prenada Media Group Jakarta.

[8] Sudikno Mertokusumo 2007 Mengenal Hukum Sebuah Pengantar Liberty Yogyakarta.

[9] Bachsan Mustafa 2001 Sistem Hukum Administrasi Negara Indonesia Citra Aditya Bhakti, Bandung.

[10] The Constitution of the Republic of Indonesia of 1945

[11] The Indonesian Civil Code

[12] Law No. 5 of 1960 of The Basic Regulation of the Agrarian Issues.

[13] Law No. 4 of 1996 of The Rights Dependent on the Ground with the Objects Related to the Land. 